\title{
Effect of biostimulant application on production and flavonoid content of marigold (Calendula officinalis L.) ${ }^{1}$
}

\author{
Vivian Pupo de Oliveira Machado ${ }^{2}$, Ana Claudia Pacheco ${ }^{3}$, Marcia Eugenia Amaral Carvalho $^{4}$ \\ http://dx.doi.org/10.1590/0034-737X201461060014
}

\section{RESUMO}

The production of medicinal plants as raw material for industry must associate quality with biomass formation and, with this purpose, the application of plant growth regulators has been studied in these crops. The objective of this study was to evaluate the effect of a biostimulant on growth, inflorescence production and flavonoid content in marigold. The experiment was conducted in a greenhouse and the treatments consisted of increasing doses of the biostimulant $\left(0,3,6,9,12\right.$ and $\left.15 \mathrm{~mL} \mathrm{~L}^{-1}\right)$ applied by foliar spraying in ten consecutive applications. The experiment was arranged in a completely randomized design, with six treatments and ten repetitions. The number of leaves and flowerheads and dry matter of roots increased linearly with increasing doses of the growth promoter, with $20 \%$, $36.97 \%$ and $97.28 \%$ increases, respectively, compared with the control. The total dry mass and shoot dry mass showed maximum values at the highest dose tested of $15 \mathrm{~mL} \mathrm{~L}^{-1}$ (with increases of $40.09 \%$ and $46.30 \%$, respectively). Plant height and flavonoid content reached the highest values at a dose of $6 \mathrm{~mL} \mathrm{~L}^{-1}$. The biostimulant promoted the development of marigold and positively influenced the synthesis of the secondary compound of medicinal interest. Among the tested doses, the application of rates between 6 and $9 \mathrm{~mL} \mathrm{~L}^{-1}$ of the biostimulant is recommended for more efficient large-scale production of marigold.

Key words: medicinal plant, plant growth regulators, secondary metabolism.

\section{ABSTRACT \\ Utilização de bioestimulante para incremento da produção e do teor de flavonoides em calêndula (Calendula officinalis L.)}

A produção de plantas medicinais como matéria-prima para a indústria deve associar aqualidade à formação de massa e, para tanto, o emprego de reguladores vegetais tem sido estudado nestas culturas. O objetivo deste trabalho foi avaliar o efeito de bioestimulante no crescimento, produção de inflorescências e teor de flavonoides em calêndula. $\mathrm{O}$ experimento foi conduzido em casa-de-vegetação e os tratamentos consistiram em doses crescentes do bioestimulante $\left(0,3,6,9,12\right.$ e $\left.15 \mathrm{~mL} \mathrm{~L}^{-1}\right)$, aplicadas por pulverização foliar, com dez aplicações consecutivas do produto. $\mathrm{O}$ delineamento experimental foi o inteiramente casualizado, com seis tratamentos e dez repetições. $\mathrm{O}$ número de folhas e de capítulos florais e a massa da matéria seca de raízes aumentaram, linearmente, em função do acréscimo da dose do bioestimulante, apresentando incrementos de 20\%; 36,97\% e 97,28\% respectivamente, em relação aos do controle. As massas da matéria seca da parte aérea e total apresentaram valores máximos na maior dose testada de $15 \mathrm{~mL} \mathrm{~L}^{-1}$ (com acréscimos de 40,09 e 46,30\%, respectivamente). Por outro lado, a altura de plantas

\footnotetext{
Received: 29/05/2013; Approved: 25/06/2014.

${ }^{1}$ Part of the first author's dissertation.

${ }^{2}$ Nutritionist, Master of Science. Programa de Pós-Graduação em Produção Vegetal da Universidade do Oeste Paulista, Rodovia Raposo Tavares, Km 572, 19067-175, Presidente Prudente, São Paulo, Brasil. prof.vivianpupo@hotmail.com

${ }_{3}^{3}$ Agronomist, Doctor of Science. Programa de Pós-Graduação em Produção Vegetal da Universidade do Oeste Paulista, Rodovia Raposo Tavares, Km 572, 19067-175, Presidente Prudente, São Paulo, Brasil. anaclau@ unoeste.br (corresponding author).

" Biologist, Master of Science. Genética e Melhoramento de Plantas na Escola Superior de Agricultura "Luiz de Queiroz", Avenida Pádua Dias, 11, 13418-900, Piracicaba, São Paulo, Brasil.marcia198807@ hotmail.com
} 
e o teor de flavonoides alcançaram os maiores valores na dose de $6 \mathrm{~mL} \mathrm{~L}^{-1}$. A aplicação de bioestimulante promove o desenvolvimento da calêndula, influenciando positivamente também a síntese do composto secundário de interesse medicinal. Dentre as doses testadas, a aplicação de concentrações entre 6 e $9 \mathrm{~mL} \mathrm{~L}^{-1}$ do bioestimulante é indicada para tornar mais eficiente o sistema de produção vegetal da calêndula para a utilização em larga escala.

Palavras-chave: planta medicinal, reguladores de crescimento vegetal, metabolismo secundário.

\section{INTRODUCTION}

Calendula officinalis L. (Asteraceae), (marigold), is used worldwide as a medicinal plant due to its antiinflammatory and wound healing properties (Rodrigues et al., 2004). The inflorescences of marigold have different potentially active chemical components, including essential oils, saponins, flavonoids and carotenoids, among others (Bilia et al., 2002). However, the flavonoids have pharmacological activity of greater importance and are represented, in most cases, by rutin and quercetin, which are also used as markers to ensure the quality of the raw material (Kurkin \& Sharova, 2007).

In growing medicinal plants, it is very important to associate the biomass production to quality of the raw material. Studies about the effect of plant growth regulators (PGRs) on the accumulation of secondary metabolites in medicinal plants have been conducted in order to increase the medicinal and trade values of these species (El-Hady, 2005; Barreiro et al., 2006; Pov \& Ono, 2006).

A mixture of two or more PGRs or these with other substances (amino acids, nutrients, vitamins) is called a plant growth promoter or biostimulant. Biostimulants are effective when applied in small doses, thus favoring the plant development, allowing production optimization (Castro \& Vieira, 2001). Biostimulant efficiency is attributed to the mobility of PGRs within the plant, the potential for signal amplification and the ability to promote complex regulatory actions through interactions between different biochemical and physiological events (Diniz et al., 2009). However, there is a high variability in the effects of PGRs or biostimulants on plants, depending on the crop, environment and agricultural practices.

Interesting results have been obtained with the application of PGRs in marigold. Pacheco et al. (2013) observed linear increases in biomass production, number of inflorescences and flavonoid content in inflorescences of marigold with foliar application of salicylic acid, at concentrations of $0.0 ; 0.25 ; 0.5$ and 1.0 $\mathrm{mM}$. Hashemabadi et al. (2012) reported that the joint application of the growth retardants Cicocel and
Daminozide resulted in increased number of leaves and inflorescences per plant and essential oil content in flowers of this species. However, specific records on the application of plant biostimulants in marigold are lacking in the literature.

Therefore, the aim of this study was to evaluate the effects of a biostimulant applied via foliar spraying on growth, inflorescence production and flavonoid content in marigold.

\section{MATERIALS AND METHODS}

The experiment was conducted in a greenhouse, in non-controlled temperature and humidity conditions, in Avare-SP (230' $55^{\prime \prime} \mathrm{S}$ latitude, $48^{\circ} 55^{\prime} 33^{\prime \prime} \mathrm{W}$ longitude, average altitude of $780 \mathrm{~m}$ ), subtropical climate, wet winter and South wind predominance, according to Koppen.

The seedlings were obtained from commercial seeds of marigold (cv. Dobrada Sortida), germinated in 200cell plug trays containing organic substrate. Seedlings were transplanted to $5-\mathrm{kg}$ pots, 40 days after planting (DAP). The pots containing a mixture of organic substrate, loam and sand (in the ratio 1:1:1). Irrigation was performed manually during all the period of the experiment.

The treatments consisted of different biostimulant doses (aqueous solutions) applied manually by foliar spraying on the leaves to the drip point. The biostimulant consisted of cytokinin $\left(90 \mathrm{mg} \mathrm{L}^{-1}\right)$, auxin $\left(50 \mathrm{mg} \mathrm{L}^{-1}\right)$ and gibberellic acid (50 $\left.\mathrm{m} \mathrm{L}^{-1}\right)$ (Stoller do Brasil, 1998). The doses were: $\mathrm{T} 1=0 \mathrm{~mL} \mathrm{~L}^{-1}$ (distilled water only); $\mathrm{T} 2$ $=3 \mathrm{~mL} \mathrm{~L}^{-1} ; \mathrm{T} 3=6 \mathrm{~mL} \mathrm{~L}^{-1} ; \mathrm{T} 4=9 \mathrm{~mL} \mathrm{~L}^{-1} ; \mathrm{T} 5=12 \mathrm{~mL} \mathrm{~L}^{-}$ ${ }^{1}$ and $\mathrm{T} 6=15 \mathrm{~mL} \mathrm{~L}^{-1}$. The treatments started 20 days after transplanting (DAT) the seedlings to pots, with ten consecutive applications of the product in the early hours of the morning.

After the treatments, biometric evaluations of the plant growth were performed: height and number of leaves at 30,60 and 90 DAT (from beginning to end of the vegetative phase) and shoot and root dry matter at 90 DAT (beginning of the reproductive phase, time of maximum biomass accumulation). Plant height was 
measured with a metric ruler. For biomass determination, five plants of each treatment were collected at random, and shoot and root system were separated. The material was dried in an oven with air circulation at $60{ }^{\circ} \mathrm{C}$ to constant mass.

At the beginning of flowering (80 DAT), the inflorescences were harvested ( 5 plants per treatment) at a frequency of two to three times per week until the end of the cycle. The total number of inflorescences per plant and fresh and dry matter of inflorescences were recorded. The dried inflorescences were kept in polyethylene bags coated with kraft paper until the phytochemical analysis. Inflorescence flavonoid determination was carried out according to Verlag (1978) and modified so that quercetin was used as a standard, in solution of methanol and aluminum chloride. The absorbance readings were performed at $420 \mathrm{~nm}$ in a UV/ visible spectrophotometer (Beckman DU 70) for total flavonoid concentration $\left(\mathrm{mg} \mathrm{L}^{-1}\right)$. The modification consisted of the use of sodium acetate to reduce fluorescence emission of the flavonoid-aluminum complex, which interferes in the spectrophotometric reading.

The experiment was arranged in a completely randomized design, with 6 treatments (biostimulant doses) and 10 repetitions, totaling 60 pots (plots), each consisting of a plant. Data were subjected to analysis of variance $(\mathrm{p}<0.05)$ and regression analysis, at 5\% probability level, using the SAS statistics software (SAS Institute, 2004). Linear and quadratic regression equations were used to express the behavior of the variables as a function of increased biostimulant doses, for the variables with significant and non-significant $F$ test, as indicated by Pimentel Gomes (2009). The number of flowerheads were transformed to $\log _{10} \mathrm{x}$, as recommended by the tool "Guided Data Analysis" of the SAS, to be according to gthe statistical assumptions of the analysis of variance. This same tool also indicated some outliers in the to be according to fresh and dry matter of the inflorescences, flavonoid content and dry mass of shoot, root and total, which were removed for the analysis of variance.

\section{RESULTS AND DISCUSSION}

The biostimulant affected significantly the height and the number of leaves (at 30 DAT), the dry matter of root and shoot, number of inflorescences and flavonoid content in marigold. The regression analysis was not significant for the other response-variables.

Figure 1A shows that the biostimulant promoted increase in height up to $6.97 \mathrm{~mL} \mathrm{~L}^{-1}$, but from this point, the higher doses caused a reduction in plant heigth.
However, the opposite occurred with the dry matter of shoot, which increased only up to $5.86 \mathrm{~mL} \mathrm{~L}^{-1}$ (Figure 2A).

The increase in height can be attributed to the presence of hormones in the formulation of the tested biostimulant, which modulates plant development. The exogenous application of gibberellins promotes internode elongation by inducing cell division and growth, thus increasing plant height (Taiz \& Zeiger, 2009). However, this hormone can decrease stem diameter and leaf size (Taiz \& Zeiger, 2009), which would explain why taller plants did not have increased shoot dry matter (Figures $1 \mathrm{~A}$ and 2A).

Tobacco plants (Nicotiana tabacum L.) grown in a greenhouse and treated with different doses of gibberellin (0.0, 1.25, 3.75 and $\left.6.75 \mathrm{~mL} \mathrm{~L}^{-1}\right)$ also showed increases in stem height (up 202.0\%) simultaneously with the reduction in dry matter (up 136.5\%) at 43 days after sowing (Almeida \& Vieira, 2010). On the other hand, the dry weight of leaves was similar or higher in plants treated with gibberellin, than the control plants. It is clear, however, that the dry matter of shoots varied little among treatments, regardless of the gibberellin dose, although the authors did not discuss this result (Almeida \& Vieira, 2010). When these plants were
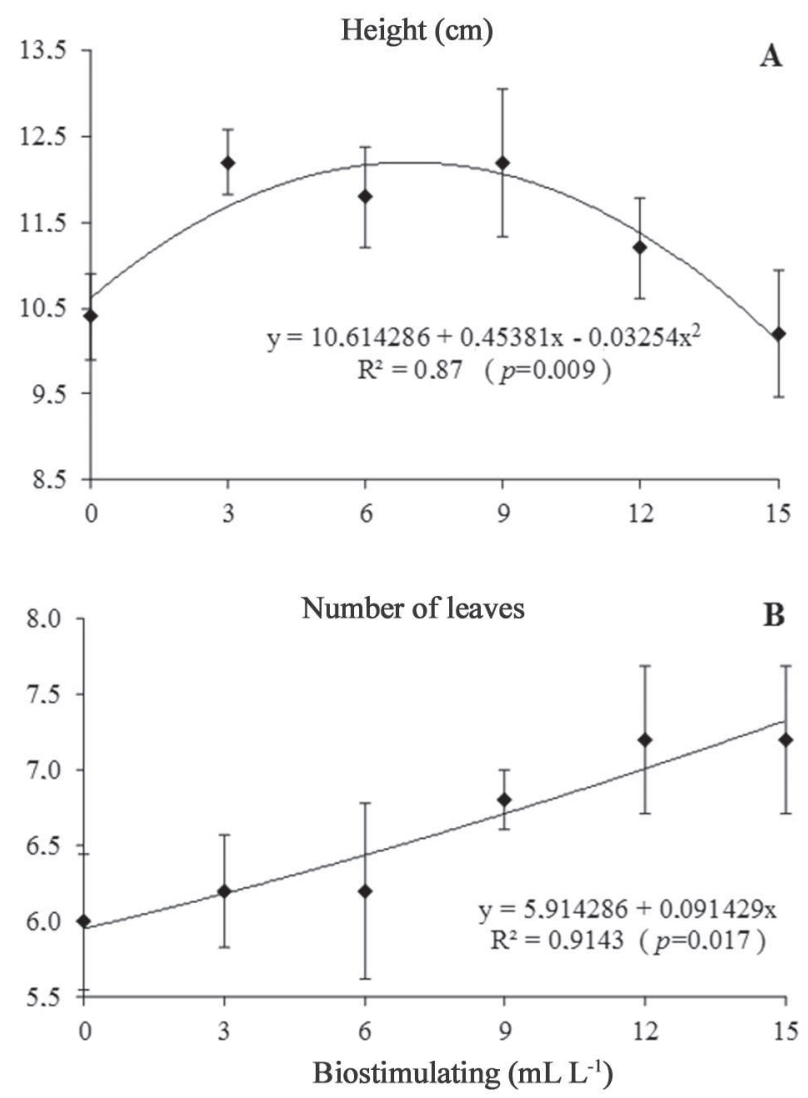

Figure 1. Height (A) and number of leaves (B) of marigold (Calendula officinalis L.) treated with increasing doses of the biostimulant, at 30 days after transplanting. 
transplanted to the field and grown to the time of harvest (107 DAP), there was a reduction in the dry matter of stems (reduction of up to $37.5 \%$, although they were taller) and dry matter of leaves (down 30.48\%) in plants treated with the hormone. However, at this stage of evaluation, there were large differences among treatments for the mean dry matter of shoots, with reductions of up to $36.35 \%$ compared with the control group. Therefore, the marigold plants had become equal in height to the time of harvest, with non-significant regression analysis at 60 and 90 DAT for this variable, there were changes in mass distribution among the plant parts by the use of the biostimulant, since the treated plants (up to the dose of $5.86 \mathrm{~mL} \mathrm{~L}^{-1}$ ) showed reduction
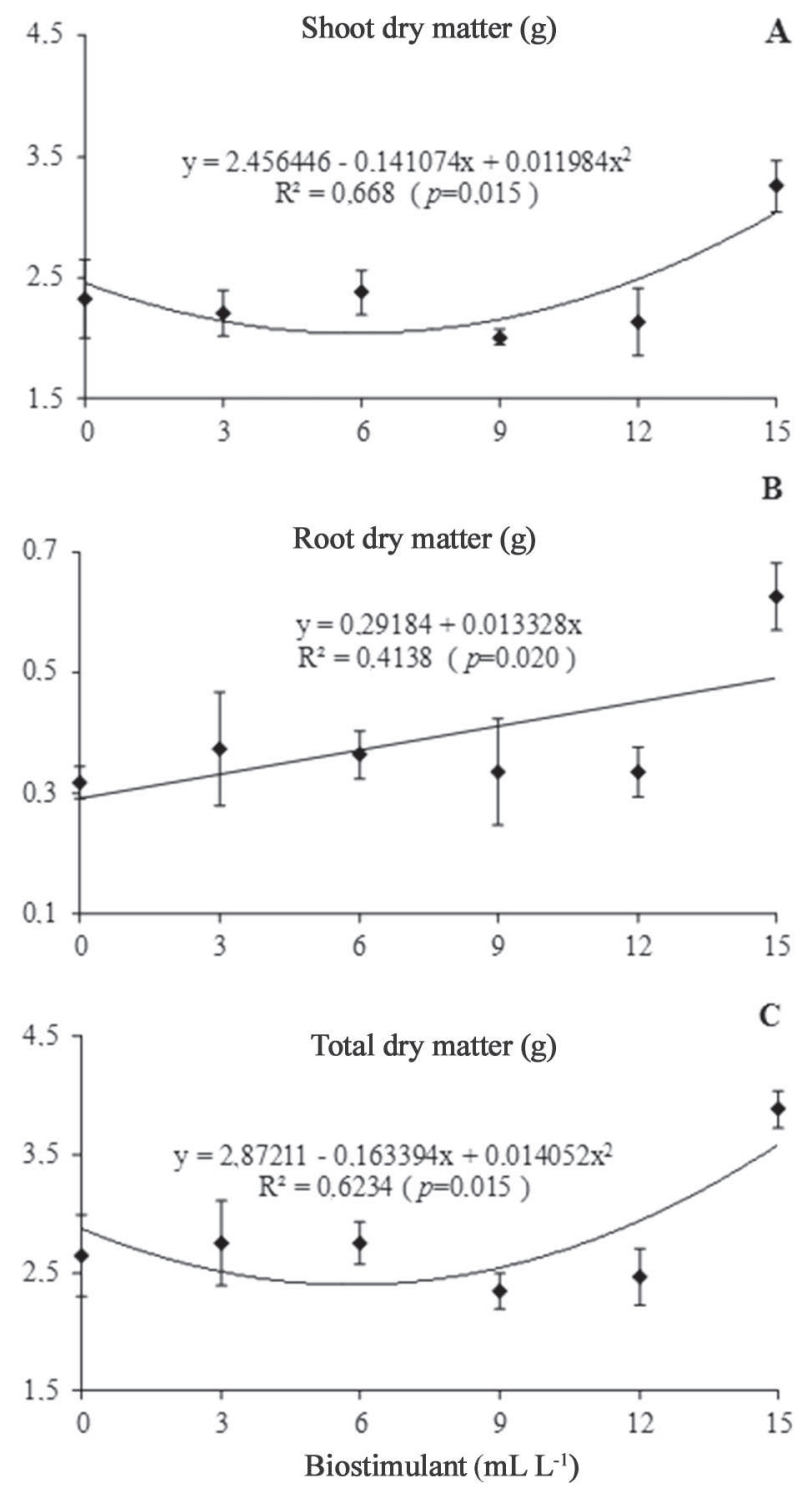

Figure 2. Dry matter of shoots (A), roots (B) and total (C - shoot dry matter plus root dry matter) of marigold (Calendula officinalis L.) treated with increasing doses of the biostimulant, at 90 days after transplanting. in the dry mass of shoots when compared with the control.

Auxin and cytokinin also directly influence plant architecture by controlling formation, maintenance and growth of the apical and axillary meristems of shoots and, therefore, the production of leaves (Taiz \& Zeiger, 2009). As seen in Figure 1B, there was a linear increase in the number of leaves with increasing biostimulant doses, in which the treated plants showed up to $20 \%$ increase compared with the control. This result is probably associated with the cytokinin, which is required during leaf formation (Werner et al., 2001), inducing the formation of a greater number of leaves per plant when present in a higher concentration in the plant (Taiz \& Zeiger, 2009).

The use of cytokinin in the cultivation in vitro of peppermint (Mentha piperita) increased the number of nodes, branches and leaves (although a reduced shoot fresh matter) and improved the performance of essential oil extraction, per fresh mass unit. It was also observed that these plants had much longer roots and with higher dry weight than those of control plants (Santoro et al., 2013).

In this study, we found that the dry matter of marigold roots increased in proportion to increase in the dose used (up to $97.28 \%$ increase compared to the control, Figure 2B), while the total dry matter had a quadratic behavior, with a maximum increase of $46.95 \%$ compared with the control after the application of $15 \mathrm{~mL} \mathrm{~L}^{-1}$ biostimulant (Figure 2C). The increase in dry matter of roots was probably related to the increased auxin, which promotes the formation of lateral roots in plants (Taiz \& Zeiger, 2009). On the other hand, Figure $2 \mathrm{C}$ shows that the total dry matter ranged similarly to the shoot dry matter (Figure 2A), an expected behavior, because the shoot dry matter is the major portion of the total dry matter.

The induction and increased flowering are among the various physiological processes that are positively affected by PGRs application (Mahgoub et al., 2006). Marigold produces flowerheads, which are used for the extraction of secondary metabolites with medicinal properties (Rodrigues et al., 2004). Thus, it is important to evaluate the amount of produced flowerheads after the application of biostimulant. In this study, there was an increasing number of flowerheads with the increase in dose of biostimulant (up to $36.97 \%$ compared with the control, Figure 3A ). However, the biostimulant did not influence the fresh and dry matter of the inflorescences (non-significant regression analysis), which can be an interesting response, since the increase in the number of inflorescences implies increasing number of physiological sinks and, hence, the competition for assimilates produced by the plant. This 
increased competition by sinks could result in the formation of less developed flowerheads (with smaller diameter and less weight), canceling out the increased flowering provided by the biostimulant.

The synergism among auxin, gibberellin and cytokinin is assumed to be responsible for the increase in crop production by the biostimulant evaluated (Castro \& Vieira, 2001). Auxin regulates the development of flower buds, while gibberellin influences the floral initiation and sexual determination and enhances plant flowering (Salisbury \& Ross, 2012; Taiz \& Zeiger, 2009). However, cytokinin seems to have a less important role in the development of reproductive organs such as flowers (Werner et al., 2001). Similar induction of flowering was reported in soybean, with increases of $62.5 \%$ in the number of flowers after application of biostimulant via seed and foliar spraying (Klahold et al., 2006).

The content of total flavonoids present in marigold inflorescences followed a quadratic curve as a function of increasing doses of the biostimulant, with the maximum point at the dose of $6.25 \mathrm{~mL} \mathrm{~L}^{-1}$ (Figure 3B). The flavonoid biosynthesis in plants is significantly affected by the application of PGRs (Ghasemzadeh \& Jaafar, 2012). In dandelion (Taraxacum officinale), treatments with salicylic acid, cytokinin and gibberellin

A
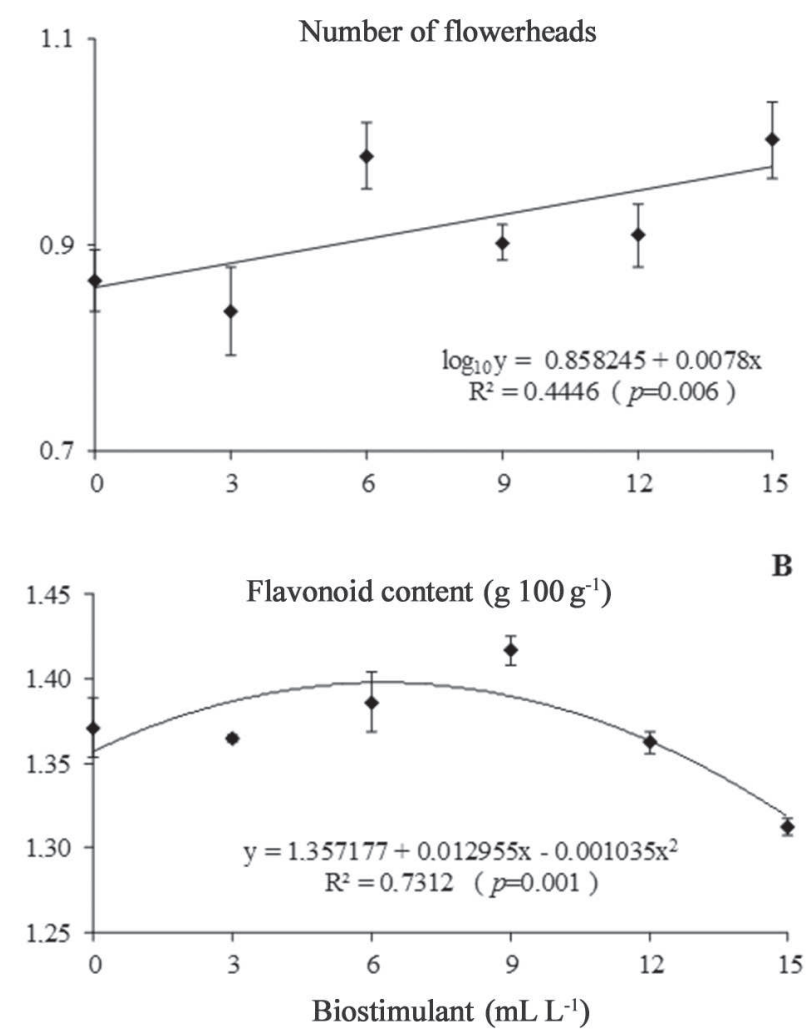

Figure 3. Number of capitula and flavonoid content of marigold (Calendula officinalis L.) treated with increasing doses of the biostimulant. resulted in increased flavonoid content in inflorescences (Kim et al., 2009). Changes in the plant hormonal status caused by PGR application possibly activates signaling pathways that regulate the expression of genes encoding enzymes related to secondary metabolism, increasing the amount or activity of these enzymes (Ghasemzadeh \& Jaafar 2012). PGRs also influence carbon partitioning in the plant, increasing the number of carbohydrate precursors required for the synthesis of phenolic compounds, including flavonoids (Singh et al., 1999).

The results obtained in this study showed that the use of biostimulants in the commercial cultivation of marigold is a viable management practice for the production of this medicinal species, increasing inflorescence production and enhancing flavonoid content. Higher content of the active substance provides higher quality of raw material and increasing its commercial value.

\section{CONCLUSIONS}

The foliar spraying of biostimulant promoted the development of marigold, increasing the number of leaves, flowerheads and the content of total flavonoids in the inflorescences.

Among the tested doses, applications ranging from 6 to $9 \mathrm{~mL} \mathrm{~L}^{-1}$ of the biostimulant were the most effective in promoting greater simultaneous production of inflorescences and active ingredient in the cultivation of marigold, as well as enhancing its use as raw material for the industry.

\section{REFERENCES}

Almeida AQ \& Vieira EL (2010) Gibberellin action on growth, development and production of tobacco. Scientia Agraria Paranaensis, 9:45-57.

Barreiro AP, Zucareli V, Ono EO \& Rodrigues JD (2006) Análise de crescimento de plantas de manjericão tratadas com reguladores vegetais. Bragantia, 65:563-567.

Bilia AR, Bergonzi MC, Gallori S, Mazzi G \& Vincieri FF (2002). Stability of the constituents of calendula, milk-thistle and passionflower tinctures by LC-DAD and LC-MS. Journal of Pharmaceutical and Biomedical Analysis, 30:613-624.

Castro PRC \& Vieira EL (2001) Aplicações de reguladores vegetais na agricultura tropical. Guaíba, Editora Agropecuária. 132p.

Diniz KA, Oliveira JA, Silva PA, Guimarães RM \& Carvalho MLM de (2009) Qualidade de sementes de alface enriquecidas com micronutrientes e reguladores de crescimento durante o armazenamento. Revista Brasileira de Sementes, 31:228-238.

El-Hady S (2005) Enhancement of the chemical composition and the yield of anise seed (Pimpinella anisum L.) oils and fruits by growth regulators. Annals of Agricultural Science, 50:15-29.

Ghasemzadeh A \& Jaafar HZE (2012) Effect of salicylic acid application on biochemical changes in ginger (Zingiber officinale Roscoe). Journal of Medicinal Plants Research, 6:790-795. 
Hashemabadi D, Lipaei SR, Shadparvar V, Zarchini M \& Kaviani B (2012) The effect of cycocel and daminozide on some growth and flowering characteristics of Calendula officinalis L., an ornamental and medicinal plant. Journal of Medicinal Plants Research, 6:1752-1757.

Kim YH, Hamayun M, Khan AL, Na CI, Kang SM, Han HH \& Lee IJ (2009) Exogenous application of plant growth regulators increased the total flavonoid content in Taraxacum officinale (Wigg). African Journal of Biotechnology, 8:5727-5732.

Klahold CA, Guimarães VF, Echer MM, Klahold A, Contiero RL \& Becker A (2006) Resposta da soja (Glycine max (L.) Merrill) à ação de bioestimulante. Acta Scientiarum Agronomy, 28:179-185, 2006.

Kurkin VA \& Sharova OV (2007) Flavonoids from Calendula officinalis flowers. Chemistry of Natural Compounds, 43: 216-217.

Mahgoub MH, Aziz NGAE \& Youssef AA (2006) Influence of foliar spray with paclobutrazol or glutathione on growth, flowering and chemical composition of Calendula officinalis L. plant. Journal of Applied Sciences Research, 2: 879-883.

Pacheco AC, Cabral AS, Fermino ESS \& Aleman CC (2013) Salicylic acid-induced changes to growth, flowering and flavonoids production in marigold plants. Journal of Medicinal Plants Research, 1:95-100

Pimentel- Gomes F (2009) Curso de Estatística Experimental. Piracicaba, Nobel. 468p.

Povh JA \& Ono EO (2006) Rendimento de óleo de Salvia officinalis L. sob ação de reguladores vegetais. Acta Scientiarium Agronomy, 28: 189-193.

Reis MS, Mariot A \& Steenbock W (2007) Diversidade e domesticação de plantas medicinais. In: Simões CMO, Schenkel EP, Gosmann G Mello JCP, Mentz LA \& Petrovick PR (Eds.) Farmacognosia: da planta ao medicamento. Porto Alegre, Editora da UFRGS / Florianópolis, Editora da UFSC. p. 45-74.
Rodrigues PO, Gonçalves TC \& Silva WB (2004) Influência de diferentes sistemas de solventes no processo de extração de Calendula officinalis L. (Asteraceae). Acta Farmaceutica Bonaerense, 23: 2731.

Salisbury FB \& Ross CW (2012) Fisiologia das plantas. São Paulo, Cengage Learning. 774p.

Santoro MV, Nievas F, Zygadlo J, Giordano W \& Banchio E (2013) Effects of growth regulators on biomass and the production of secondary metabolites in peppermint (Mentha piperita) micropropagated in vitro. American Journal of Plant Sciences, 4: 4955 .

SAS Institute (2004) SAS/STAT User's Guide: Version 9.1. Cary, SAS Institute. 4975p.

Singh P, Srivastava NK, Mishra A \& Sharma S (1999) Influence of ethereal and gibberellic acid on carbon metabolism, growth, and essential oil accumulation in spearmint (Mentha spicata). Photosynthetica, 36: 509-517.

Stoller do Brasil (1998) Stimulate Mo em hortaliças. Cosmópolis, Stoller do Brasil. (Informativo Técnico).

Taiz L \& Zeiger E (2009) Fisiologia vegetal. Porto Alegre, Artmed. 819p.

Verlag DA (1978) Deutsches Arzeibuch. Gogi-Verlag GmBH: Stuttgart, Germany. 680p.

Werner T, Motyca V, Strnad M \& Schmulling T (2001) Regulation of plant growth by cytokinin. Proceedings of the National Academy of Sciences of the United States of America, 98:10487-10492. 